DOI:10.22337/2587-9618-2018-15-1-61-66

\title{
THE NEW PHYSICALLY NONLINEAR FINITE ELEMENTS IN SOFTWARE PACKAGE LIRA 10.8
}

\author{
Yuriy D. Geraymovich, Isaak D. Yevzerov, Dmitriy V. Marchenko \\ LIRA Group of Companies, Kiev, UKRAINE
}

\begin{abstract}
The new physically nonlinear finite elements, based on the theory of elastic plasticity, are proposed for bending rods and plates. These new elements can be used for static and dynamic problems, including seismic. The iterative method is used for static problems, the finite differences method - for dynamic.
\end{abstract}

Keywords: elastic plasticity, iterative method, finite differences method

\section{НОВЫЕ ФИЗИЧЕСКИ НЕЛИНЕЙНЫЕ КОНЕЧНЫЕ ЭЛЕМЕНТЫ В ПРОГРАММНОМ КОМПЛЕКСЕ ЛИРА 10.8}

\author{
Ю.Д. Гераймович, И.Д. Евзеров, Д.В. Марченко \\ Группа компаний «ЛИРА», г. Киев, УКРАИНА
}

\begin{abstract}
Аннотация: Предлагаются новые физически нелинейные конечные элементы изгибаемых стержней и пластин, основанные на теории упруго-пластичности. Эти новые элементы могут применяться как для статических, так и для динамических расчетов, в том числе и для решения задач сейсмики. В статической задаче применяется шагово-итерационный метод, в динамической - метод конечных разностей.
\end{abstract}

Ключевые слова: упруго-пластичность, итерационный метод, метод конечных разностей

\section{INTRODUCTION}

In the previous versions of the LIRA software package (SP LIRA), physically nonlinear finite elements (FE) for bending rods and plates, based on the nonlinear theory of elasticity, were realized. These FE are successfully used for static calculations, but are not applicable to dynamics problems. Then, two-dimensional and three-dimensional physically nonlinear FE, based on the theory of elastic-plasticity, were developed. These elements are used for both static and dynamic calculations, but they do not solve bending problems. In the version of SP LIRA 10.8 new physically nonlinear $\mathrm{FE}$ of bending rods and plates are proposed, based on the theory of elastic-plasticity. These new elements have all the possibilities that physically nonlinear bending elements have - the same set of loads, shear calculation, the presence of an elastic basis, which can be one-sided. New elements can be used for both static and dynamic calculations, including seismic problems. The stepwise iteration method is used in the static problem, the finite difference is applied in the dynamic problem the finite difference method is applied. Convergence is proved in [1].

Dependences between stresses and strains in the theory of elastic-plasticity are studied in [2]. Let us introduce in stress space

$$
\sigma=\left\{\sigma_{i j}\right\}
$$

a closed convex set $\mathrm{K}$, which contains point $\mathrm{O}$, determined by inequality

$$
\Phi(\sigma) \leq 0,
$$

where $\Phi(\sigma)$ - continuous convex function. Denote as $\mathrm{P}_{\mathrm{K}}(\sigma)$ nearest to $\sigma$ point of set $\mathrm{K}$, 


$$
g(\sigma)=\sigma-\mathrm{P}_{\mathrm{K}}(\sigma)
$$

where $g(\sigma)=0$ if $\sigma \in \mathrm{K}$. Assume that the strains $\varepsilon_{i j}$ are sums of elastic and plastic deformations, where elastic deformations satisfy Hooke's law, whereas velocities of plastic deformations are equal to vector $g(\sigma)$. Inequalities, which determine set $\mathrm{K}$, are formulated in terms of main stresses $\sigma_{i}, i=1,2,3, \sigma_{1} \geq \sigma_{2} \geq \sigma_{3}$, or invariants

$$
\begin{gathered}
S_{1}=\sigma_{1}+\sigma_{2}+\sigma_{3}, \\
S_{2}=\sqrt{\left(\sigma_{1}-\sigma_{2}\right)^{2}+\left(\sigma_{2}-\sigma_{3}\right)^{2}+\left(\sigma_{3}-\sigma_{1}\right)^{2}} .
\end{gathered}
$$

Prandtl model

$$
R_{c} \leq \sigma_{i} \leq R_{s}
$$

for rods and Geniev model

$$
\Phi(\sigma)=-\left(R_{c}+R_{s}\right) S_{1} / 3+S_{2}^{2}+R_{c} * R_{s}
$$

for plates are used, $R_{c} \leq 0 \leq R_{s}$ are uniaxial compression and tension limits.

\section{EXAMPLES}

Examples of static and dynamic problems solution with new physically nonlinear finite elements of bending rods and plates, based on the nonlinear theory of elasticity, are given.

\section{An example of solving a static problem.}

As an example, demonstrating the differences in the work of physically nonlinear and elastically plastic FE, a cantilever beam loaded with a uniformly distributed load of intensity $\mathrm{q}=12 \mathrm{tf} / \mathrm{m}$ is considered and then unloaded by a uniformly distributed load of the same intensity. Simulation was performed by both rod and shell FE. The rod (FE 210) and shell (FE 244) physically nonlinear FE and rod (FE 510) and shell (FE 544) elastic-plastic FE were used. The calculation scheme consists of 5 elements (Figure 1). All the dimensions in figure 1 are given in millimeters. The cross-section of the cantilever beam is reinforced with one rod $56 \mathrm{~mm}$ in diameter, installed as shown in Figure 1.

Diagrams of work and numerical values describing the law of deformation for concrete and reinforcement are shown in figure 2 and Figure 3.

The load is selected so that approximately 10 percent does not reach the limit moment. In Figure 4, vertical displacements $(Z)$ of the free edge of the console are superimposed in the case of simulation by the rod (FE 210) and shell (FE 244) physically nonlinear FE.

In Figure 5, vertical displacements $(Z)$ of the free edge of the console are superimposed in the case of modeling by elastic (FE 510) and shell (FE 544) elastic-plastic FE.

The static task is considered in the above example. The first part of the graph (from 0 to 1 ) is the process of loading the calculation scheme, the second part of the graph (from 1 to 2) is the process of unloading the calculation scheme. It is easy to see that under load the results for physically nonlinear and for elastic-plastic finite elements are very close. When unloading, there are residual deformations in elastic-plastic elements (figure 5).

\section{An example of solving a dynamic problem.}

The solution of the dynamic problem and comparison with the results obtained in the ANSYS finite element analysis package are given below. Here, too, a cantilever beam of square cross section was considered for a seismic action given in the form of an accelerogram of an earthquake (Figure 6).

The damping was represented by a damping matrix in the Rayleigh form $C=\alpha \cdot M+\beta \cdot K$, with the following parameter values $\alpha=$ $0.0 \mathrm{sec}^{-1}, \beta=0.0023016 \mathrm{sec}$. 
The New Physically Nonlinear Finite Elements in Software Package LIRA 10.8
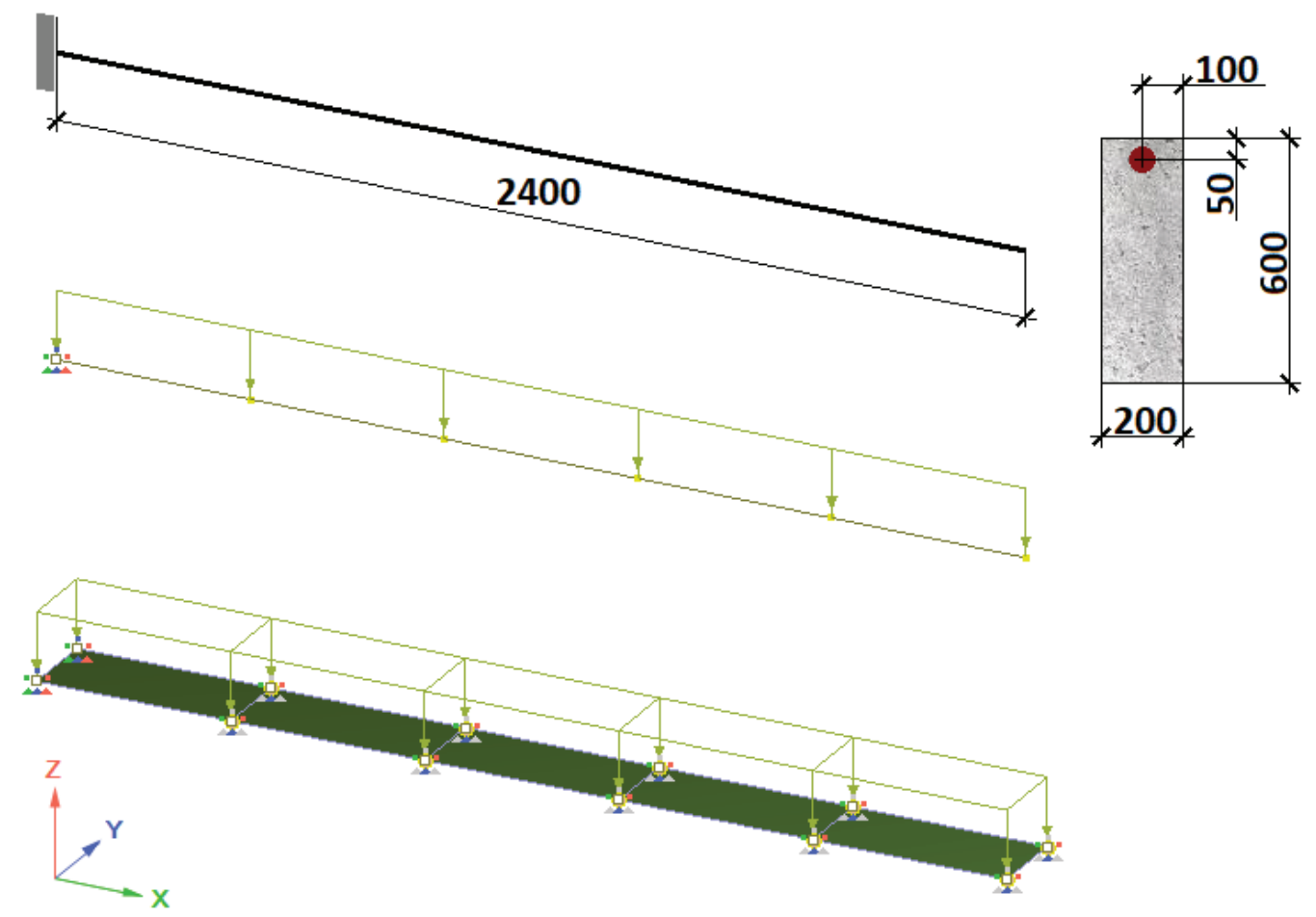

Figure 1. Calculation scheme of the static problem.

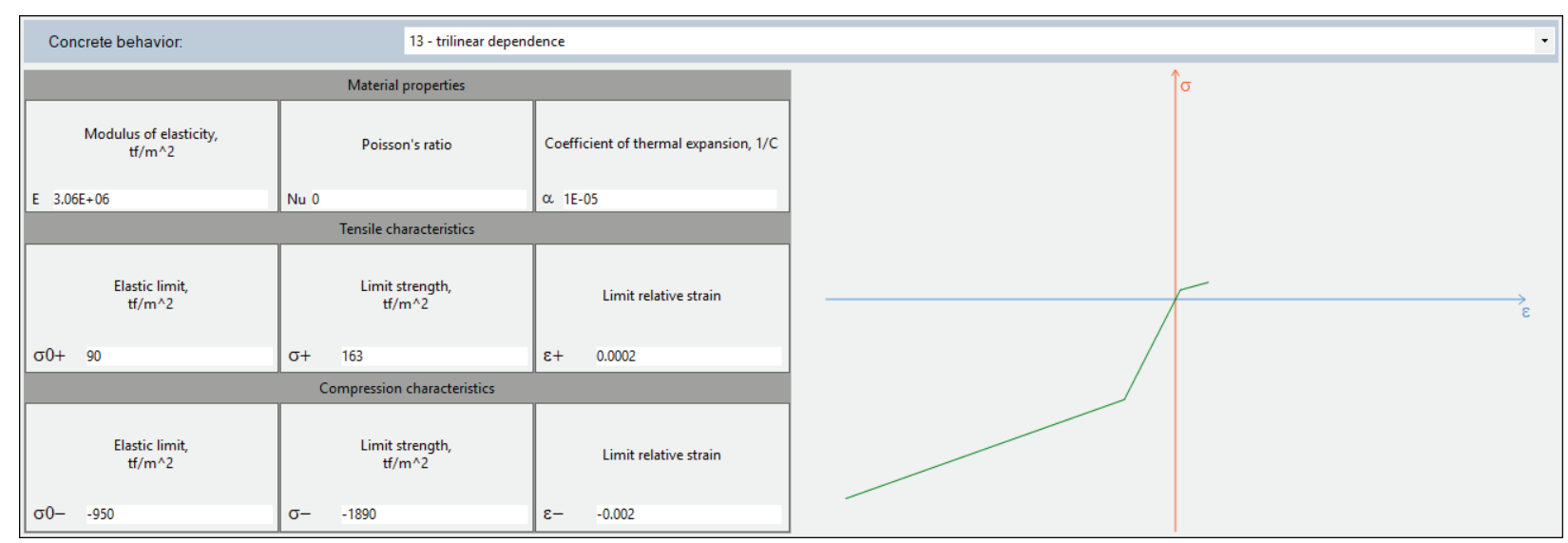

Figure 2. The diagram of the work of concrete.

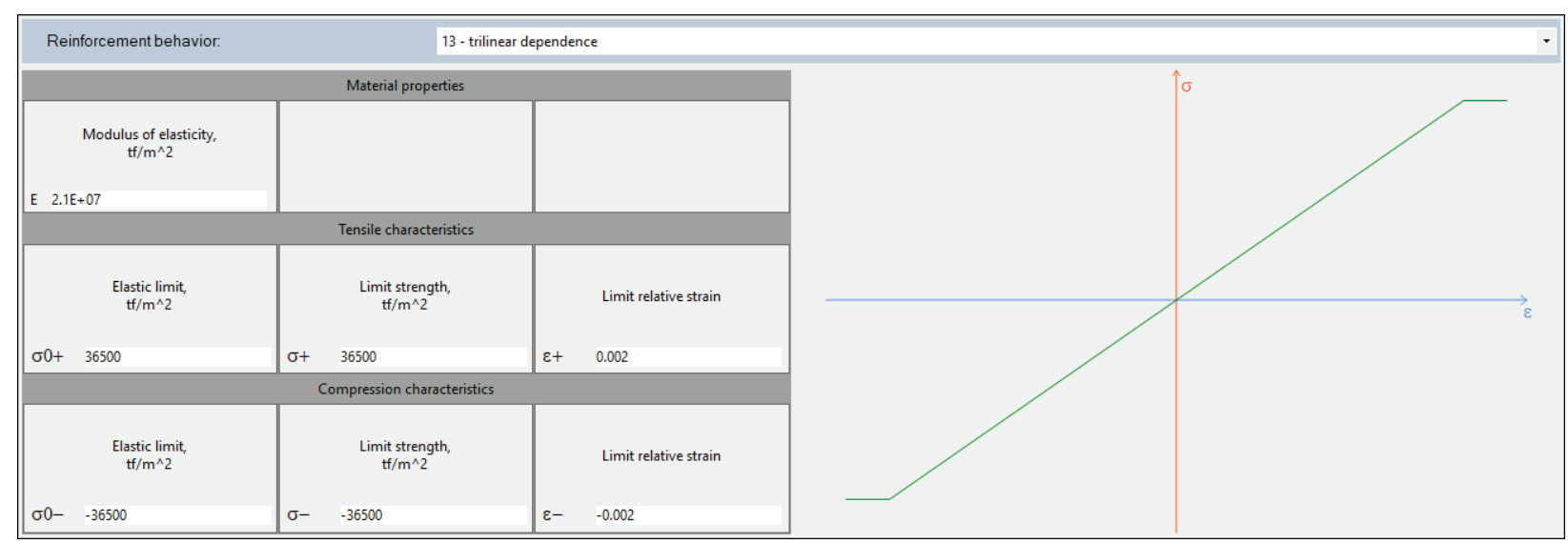

Figure 3. The diagram of the work of reinforcement. 


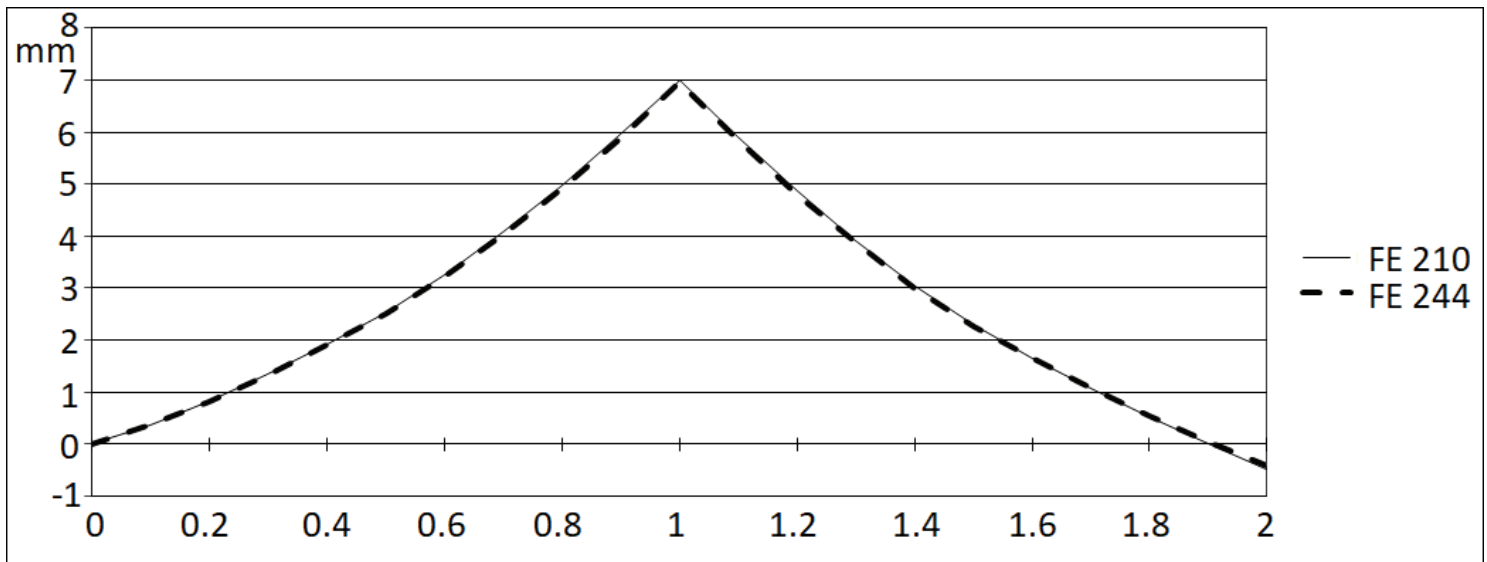

Figure 4. Displacements of the free edge when modeling physically nonlinear FE.

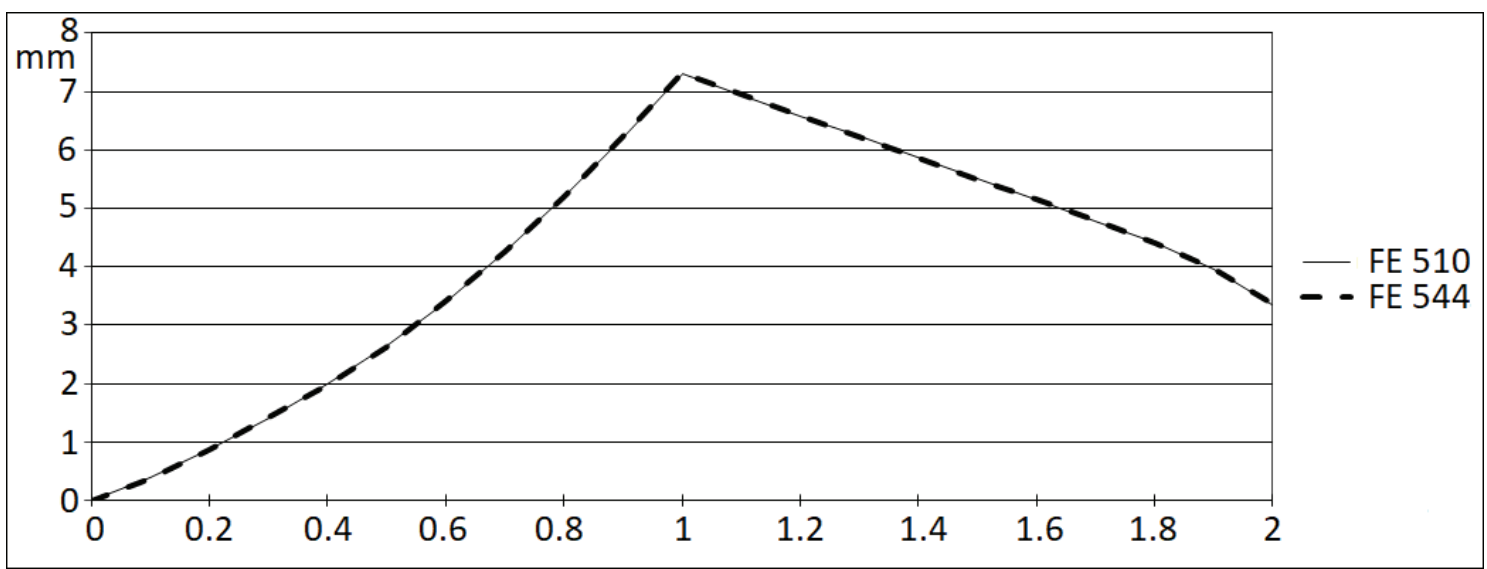

Figure 5. Displacements of the free edge when modeling elastic-plastic FE.
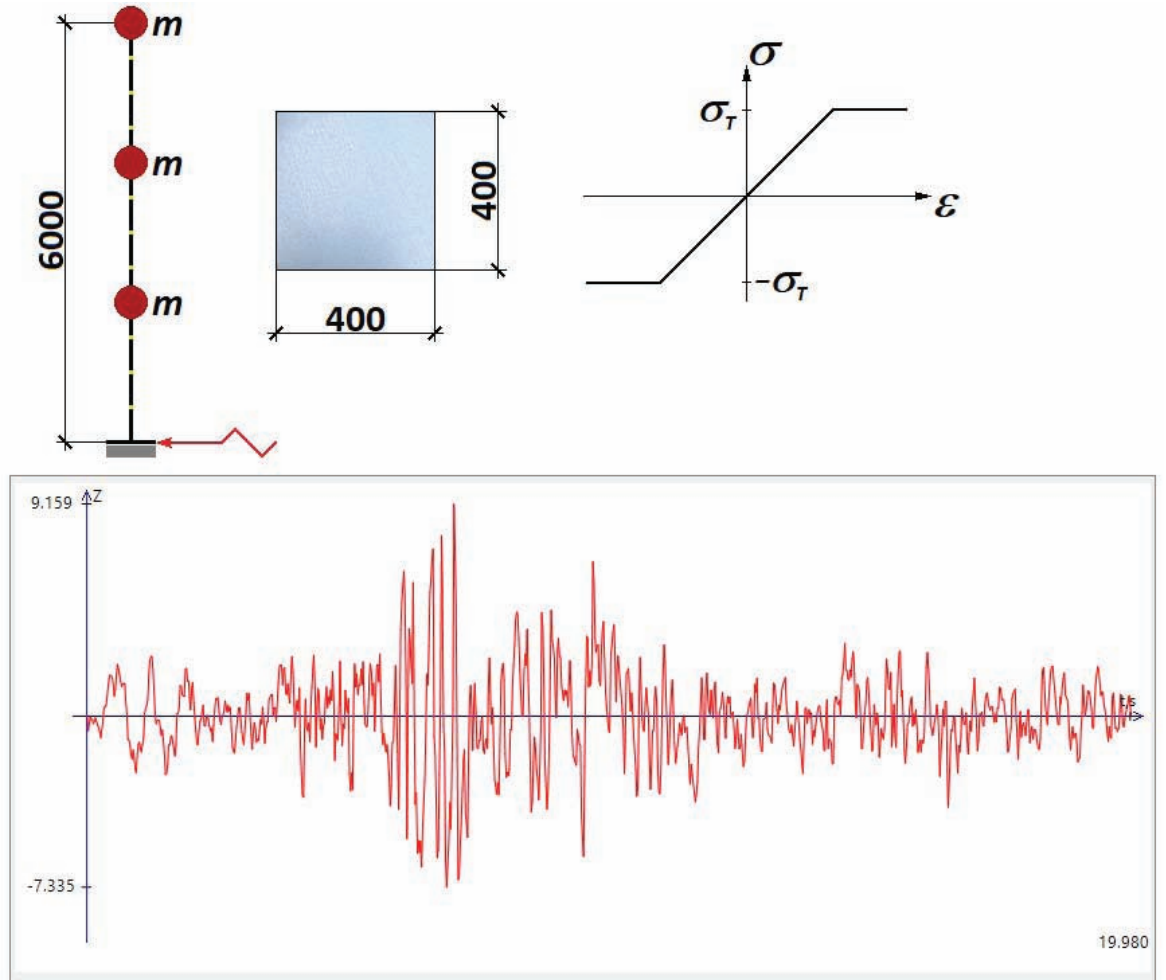

Figure 6. Calculation scheme of the dynamic problem. 


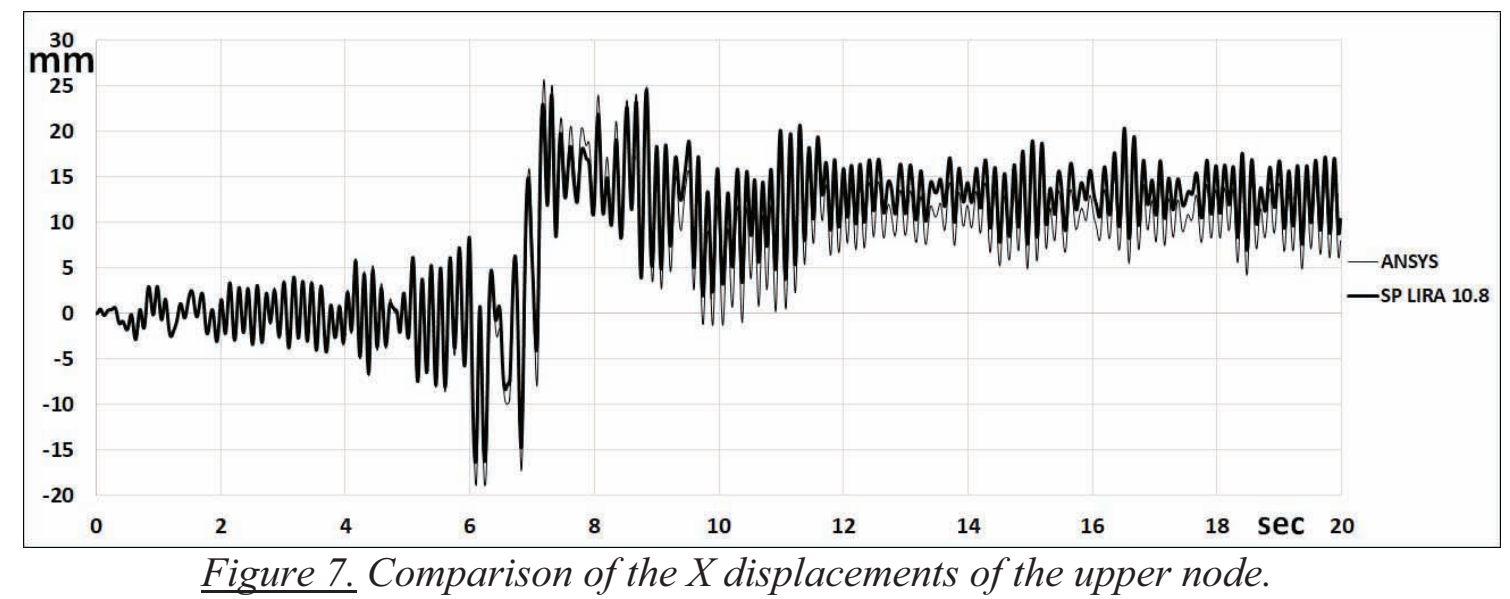

The initial modulus of elasticity is equal to

$$
E=2.0 e 7 \frac{t f}{m^{2}}
$$

yield strength

$$
\sigma_{T}=2000 \frac{t f}{m^{2}}
$$

All the dimensions in Figure 6 are given in millimeters.

First, a linear dynamic problem was solved, the results of which showed a complete coincidence between the SP LIRA 10.8 and ANSYS. Next, we solved a nonlinear dynamic problem, whose results are shown in Figure 7, in the form of graphs of the time variation of the $\mathrm{X}$ displacements of the upper node.

Thanks to the new nonlinear FE, based on the theory of elasticity, the developers of SP LIRA 10.8 (http://www.lira10.com) provided an opportunity for the practical use of direct dynamic calculation by design engineers. The structure of the SP LIRA 10.8 includes a specialized calculation and graphic system DYNAMICS+ for calculating structures for arbitrary dynamic effects by the method of direct integration of the equations of motion in linear and nonlinear formulations. Below is a brief description of the capabilities of this system:

- setting of time-dependent loads, such as polyline with equidistant and variable steps, harmonic load, accelerogram and earthquake seismogram;

- animation of the integration process;
- plotting of graphs as time functions for displacements and stress components in selected nodes and elements;

- visualization of diagrams, mosaics and isofields for the components of displacements and stresses in selected nodes and elements at the current time;

- tables of the results of the values of the displacement and stress components in the selected nodes and elements.

\section{REFERENCES}

1. Gorbovets A.V., Yevzerov I.D. Priblizhennyye Skhemy Dlya Statsionarnykh i Nestatsionarnykh Zadach s Odnostoronnimi Ogranicheniyami [Approximate Schemes for Stationary and Non-Stationary Problems with One-Sided Constraints]. // Vychislitel'nyye Tekhnologii, 2000, Vol. 5, No. 6, pp. 33-35 (in Russian).

2. Duvaut G., Lions J.-L. Les Inequanionsb en Mecanique en Physique. Paris, Dunod, 1972, 383 pages.

\section{СПИСОК ЛИТЕРАТУРЫ}

1. Горбовец А.В., Евзеров И.Д. Приближенные схемы для стационарных и нестационарных задач с односторонними ограничениями. // Вычислительные технологии, 2000, том 5, №6, с. 33-35. 
2. Duvaut G., Lions J.-L. Les Inequanionsb en Mecanique en Physique. Paris, Dunod, 1972, 383 pages.

Yurii D. Heraimovych, Cand. Sc. (Tech.), PRIME CAD LLC, executive director, office 216, 6-A, Kadetskiy Gay str., 03048, c. Kiev, Ukraine, phone +38 (044) 246-16-20, E-mail: mdv@lira.com.ua

Isaak D. Ievzerov, Dr. Sc. (Tech.), VEGA CAD LLC, director, office 209, 6-A, Kadetskiy Gay str., 03048, c. Kiev, Ukraine, phone +38 (044) 520-05-23,

E-mail: ide@lira.com.ua

Dmytro V. Marchenko PRIME CAD LLC, lead engineer, office 216, 6-A, Kadetskiy Gay str., 03048, c. Kiev, Ukraine, phone. +38 (044) 246-16-20,

E-mail: yury@lira.com.ua

Гераймович Юрий Дмитриевич, кандидат технических наук, старший научный сотрудник; ООО ПРАЙМ КАД, исполнительный директор, оф. 216, 6а, ул. Кадетский Гай, 03048, г. Киев, Украина,

тел. (+38 044) 246-16-20; E-mail: mdv@lira.com.ua.

Евзеров Исаак Данилович, доктор технических наук, старший научный сотрудник; ООО ВЕГА КАД, директор, оф. 209, ба, ул. Кадетский Гай, 03048, г. Киев, Украина, тел. (+38 044) 520-05-23;

E-mail: ide@lira.com.ua.

Марченко Дмитрий Владимирович, ООО ПРАЙМ КАД, ведущий инженер, оф. 216, ба, ул. Кадетский Гай, 03048, г. Киев, Украина, тел. (+38 044) 246-16-20;

E-mail: yury@lira.com.ua. 